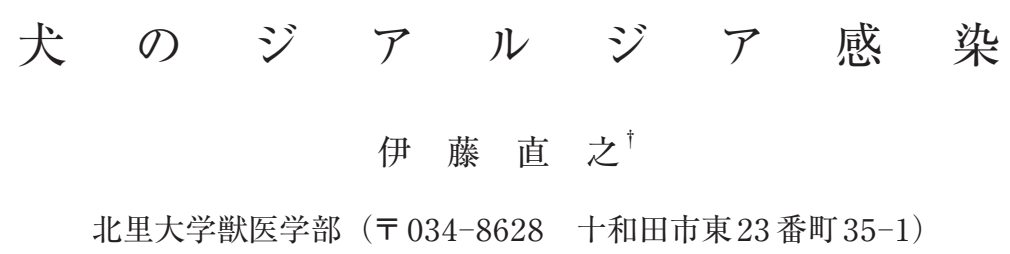

Giardia infection in dogs

Naoyuki $\mathrm{ITOH}^{\dagger}$

Kitasato University, School of Veterinary Medicine, Higashi 23-35-1, Towada, 034-8628, Japan

ジアルジア（Giardia）は世界中に広く分布し，人や 犬をはじめとしたさまざまな動物の消化管内に寄生して 下痢の原因となることがある最も一般的な原虫の一つで ある。この原虫に関する研究は，1681年のレーウェン フックによる発見からはじまり，数多くの論文が毎年発 表されている。しかしながら，病態発生機序を含め，現 在に至っても未解決な部分が多い寄生虫でもある。

犬のジアルジアに関しては, 最近, 日本国内でも診断 用のELISA キットが使用可能になったこともあり，以 前に比較して認知度が高まっているように思われる．本 総説では，これまで著者が実施してきた疫学調査の成績 を中心とした臨床に近い情報を提供したいと思う。

\section{1 ジアルジア感染の概要}

人のジアルジア感染：人におけるジアルジアの感染 は, 特に, 熱帯や亜熱帯の衛生状態がよくない発展途上 国に住む幼児を中心に地方病性に感染率が高く，世界的 な感染者数は年間約 2.8 億人に達すると推定されている [1]。また，海外では飲み水を介した水系感染による集 団発生の事例やデイ・ケアセンターなどでの排泄物の不 適切な処理による集団発生の事例が報告されている [2-5]. 人でのジアルジア感染の好発年齢は, 1 ～歳歯 の幼児や子供と, 仕事で海外, 特に発展途上国への渡航 機会が多い年齢層である $35 \sim 44$ 歳齢の成人とされてい る $[6]$.

日本国内では，人のジアルジア症は 1999 年 4 月から 施行され 2003 年 11 月に一部改正された「感染症の予防
及び感染症患者に対する医療に関する法律」で全医師に 届け出義務がある 5 類感染症に指定され，毎年 100 人前 後の患者数が報告されているが，そのほとんどは，発展 途上国から帰国した“旅行（渡航）者下痢症”の患者で ある [7].

これまで人のジアルジア感染は，上述のように水系感 染や食物を介したものが一般的だった $[2-5]$. しかしな がら最近，人と動物に共通して感染の可能性がある遺伝 子型のジアルジアが分離されたことや人と動物の距離が 近くなったことから，動物，特に人にとって身近な存在 である犬や猫から人へのジアルジア感染が危惧されるよ うになってきた $[8,9]$.

犬のジアルジア感染：犬のジアルジア感染は，子犬を 中心として急性ないしは慢性の下痢を引き起こす可能性 があり [10-12], 感染率も高いこと $[10,13-22]$, さら には，人への感染という公衆衛生学的側面からも小動物 臨床における重要な感染症の一つである.

\section{2 ジアルジアの形態}

ジアルジアには，形態学的にシスト（囊子）とトロフ オゾイト (栄養体) の二つの形態がある [23］（図 1， 2). トロフォゾイトは $12 \sim 17 \times 7 \sim 10 \times 3 \mu \mathrm{m}$ の涙滴 状（洋梨状）で，二つの大きな核と 4 対の鞭毛，腹側吸 着盤（ventral disc）と1対の中心小体を特徵とし，全 体の形は “カブトガニ”に類似している。シストは，9 〜 $13 \times 7 \sim 9 \mu \mathrm{m}$ の長円形で $0.3 \sim 0.5 \mu \mathrm{m}$ のシスト壁を 有し，不完全に分裂した二つのトロフォゾイトを包含し

\footnotetext{
$\dagger$ 連絡責任者 : 伊藤直之 (北里大学獣医学部小動物第 1 内科学研究室)

于 034-8628 十和田市東 23 番町 35-1 穴0176-23-4371 FAX 0176-23-8703

E-mail : naoitoh@vmas.kitasato-u.ac.jp

$\dagger$ Correspondence to : Naoyuki ITOH (Kitasato University, First Department of Small Animal Internal Medicine) Higashi 23-35-1, Towada, 034-8628, Japan

TEL 0176-23-4371 FAX 0176-23-8703 E-mail : naoitoh@vmas.kitasato-u.ac.jp
} 


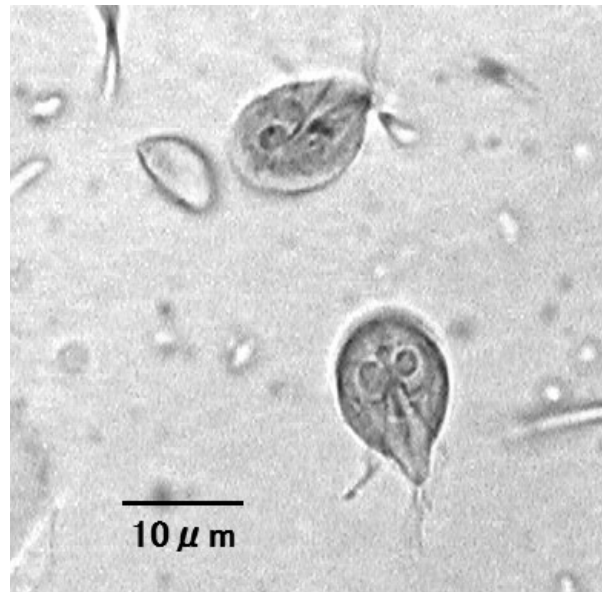

図1 ジアルジアのトロフォゾイト（ヨー ド染色)

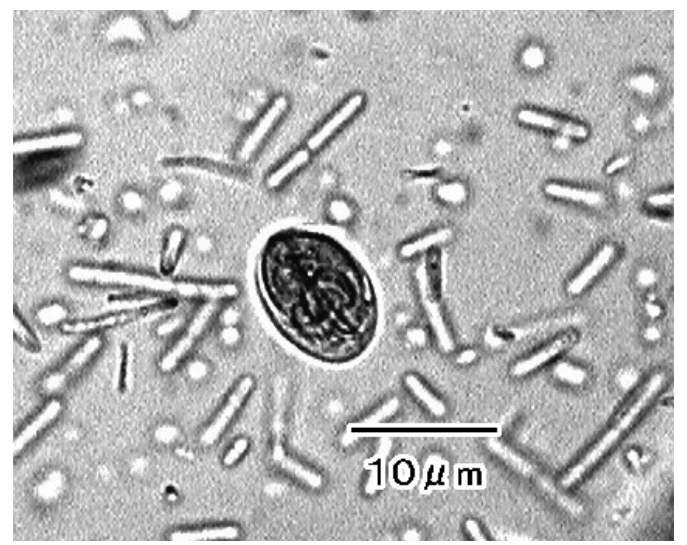

図 2 ジアルジアのシスト（ヨード染色）

て $2 \sim 4$ 個の核が認められる.なお，粪便への排泄形態 は，一般的にはシストである [23].

\section{3 ジアルジアの分類}

動物に寄生するジアルジアは，トロフォゾイトで観察 される中心小体 (median body) の形態学的特徴に基づ いて G. agilis (両生類), G. ardeae (サギ), G. duodenalis（多〈の哺乳類，シノニム; G. lamblia, G. intestinalis)，G. muris (ネズミ類)， G. psittaci (インコ）及びG. microti（マスクラット，ハ夕ネズミ) に分類されている．これらの中で，人や犬など多くの哺 乳動物に寄生するのは G. duodenalis である（以後，“ジ アルジア”は“G. duodenalis”を意味する） [23-25]. なお，G. duodenalisの同義語としてG. lambliaや G. intestinalis が用いられることがある.しかし，最近 の学術論文の記述では G. duodenalis が大半を占めてい ることから，本稿ではG. duodenalis を使用した。

\section{G. duodenalis の遺伝子型}

人と犬をはじめとした多くの哺乳類に寄生する 日獣会誌 $66 \quad 701 \sim 708 （ 2013 ）$
表 Giardia duodenalis の遺伝子型と宿主

\begin{tabular}{ccl}
\hline \hline 遺伝子型 & サブグループ & 宿主動物 \\
\hline assemblage A & I & 犬, 人, 猫など \\
& II & 人 \\
& III & 猫, 野生イノシシ \\
& IV & 猫 \\
assemblage B & & 犬, 人, 猿など \\
assemblage C & & 犬 \\
assemblage D & & 犬 \\
\hline
\end{tabular}

G. duodenalisは, assemblage $\mathrm{A} \sim \mathrm{G}$ までの7タイプ に大別されている $[8,9]$. 犬に感染する遺伝子型は, 人 獣共通の遺伝子型と考えられている assemblage A及び B と, 犬に特異的な遺伝子型である assemblage C 及び Dである。世界的に，これまで犬から分離されているジ アルジアのほとんどは，犬に固有の assemblage C また はDであり, assemblage AやBが犬から分離された例 は少ない $[6,24]$. 最近, assemblage A はさらに I IV のサブグループに分類され，例外はあるものの A- I は人と動物から， A-II は人から，そして A-III と A-IV は 動物からのみ検出されているため, assemblage Aのサ ブグループI が人獣共通感染性であると考えられている [6] (表).

遺伝子型解析の問題点：現在, ジアルジアの遺伝子型 解析には, $\beta$ giardin, TPI (triosephosphate isomerase), SSU-rRNA及びGDH (glutamate dehydrogenase）などの遺伝子が一般的に使用されている $[6$, 26, 27]. しかしながら, 使用する遺伝子によって PCR (polymerase chain reaction) の増幅率に違いがあるこ とや遺伝子型解析の結果が必ずしも一致しないことが指 摘され, PCRによるジアルジアの検出や遺伝子型解析 における問題点とされている $[26,27]$.

\section{5 感 染 経 路}

ジアルジアの感染経路は, 経口感染である，糞便内へ 排泄されたシストで污染された生水・食品を摂取するこ とや食粪による感染が一般的である $[2-5]$. また，犬の 被毛に付着したシストやハエによって機械的に運搬され るシストも感染源となり得る $[28,29]$. 感染が成立す るために必要なシストの数は，10〜 100 個と考えられ ている [30]. シストは外界の諸感作に対して比較的抵 抗性があり，水道やプールに使用される塩素消毒では死 滅せず，水分のある環境では，数力月間，感染力を持っ たまま生存可能であるとされている $[23,24]$ ，他方，卜 ロフォゾイトは外界では不安定であり，早期に死滅する ことから他の動物への感染力がないとされている $[23]$. しかしながら，犬では実験的に新鮮なトロフォゾイトの 経口摂取で感染が成立している [31]。 


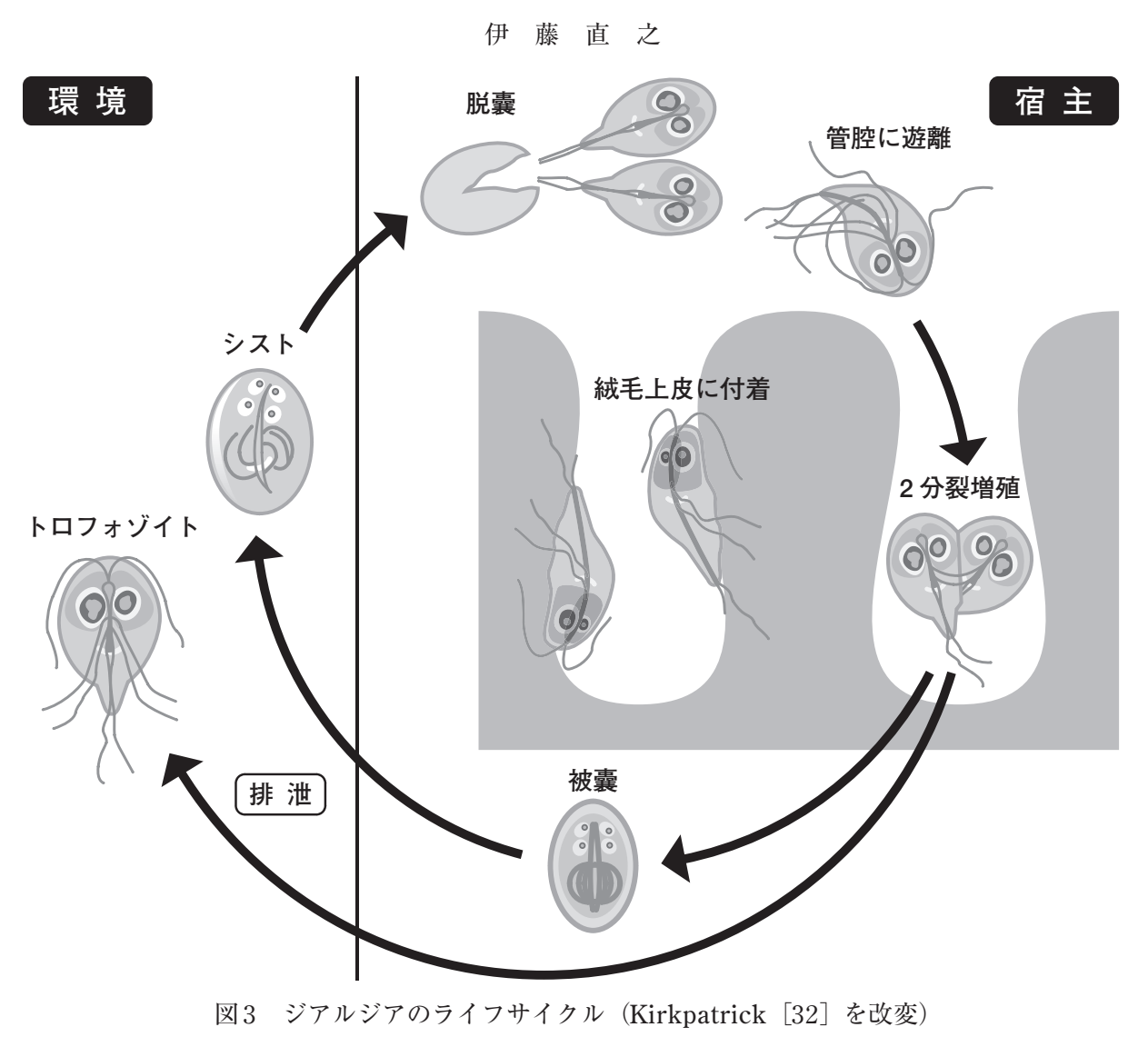

\section{6 ライフサイクル}

ジアルジアのライフサイクルは，以下のと抢りきわめ てシンプルである。糞便内のシストを経口的に撕取 $\rightarrow$ 小腸上部で脱囊（シストからトロフォゾイトが放出され る) $\rightarrow$ ロフォゾイトは絨毛上皮に付着 $\rightarrow 2$ 分裂を繰り 返して增殖 $\rightarrow$ 回腸下部・結腸で被囊（シス卜形成）－翼 便へ排泄 $[23,32,33]$ (図 3).下㾥が激しい場合には， 被囊が間に合わず糞便内にトロフォゾイトが排泄される こともある [32]. シストの経口摂取から瓷便内にシス トが排泄されるまでの期間（プレパテント・ピリオド : prepatent period）は，通常，約 $1 \sim 2$ 週間とされてい る $[23,32,33]$. シストの排泄は数力月間持続するが, 排泄パターンに規則性はなく，シストが排泄される時期 とまったく排泄されない時期があり，症例によって異な る $[23,32,34]$. また，排泄されるシストの数も一定し ない [32-34].

\section{7 症状}

人のジアルジア感染：典型的な顕性感染では, ジアル ジアの感染後 $6 \sim 15$ 日で症状を示し，急性期が $2 \sim 4$ 日 持続した後，慢性期が数週間続く [30]。ジアルジア感 染による特異的な症状はなく，急性ないしは慢性の下痢 が最も一般的であるが，不顕性感染例が多く存在するこ とも知られている $[30]$. 発症にはジアルジアの系統 （strain）や遺伝子型による病原性の違い，宿主の発育
(年齢)，栄養及び免疫状態，さらには他の寄生虫感染や ストレスに対する暴露など多様な因子が複雑に関与して いると考えられている [30].

犬のジアルジア感染：臨床症状としては，粘血便をと もなった急性ないしは慢性の下痢, 食欲減退, 腹痛など が報告されているが $[10,11,32] ，$ いずれも人と同様に ジアルジア感染に特異的なものではない，また，症状を 示す例に比べて不顕性感染例が多数存在する $[10,11$, 32]．特に子犬では，発症に輸送や環境の変化などのス トレスが関与していると推測されている $[11]$. 著者も 開業当時に，ペットショップから購入直後は正常便であ ったものが，2３日後に下㾥便を排泄するようになり 来院し，ジアルジアが検出された例を多く経験してい る。また，ジアルジアが検出されたにもかかわらず，糞 便性状や一般状態に変化がないことから飼育者が治療を 希望しなかったが，数日後に下㾥便を排泄して再来院す る子犬もしばしば経験した。な扔，臨床症状と糞便に排 泄されるシストの数には関連性がないとされている [32].

\section{8 ジアルジアの病態生理}

ジアルジア感染による下痢の発生メカニズムは，解明 されていない，以前は，増殖したジアルジアが機械的バ リアーとして働き小腸における吸収を妨げることやジア ルジアが産生するトキシンが下㾥の発生に関係があると されてきたが $[23,30,35]$ ，現在ではいずれも否定的で 
ある、マウスとジャービルの感染実験では，ジアルジア の寄生にともなう粘膜表面の傷害により，リパーゼ，プ ロテアーゼ及びジサッカリダーゼなどの消化酵素活性の 低下が示されている $[30,32,36]$. ジアルジアが産生す る排泄性及び分泌性の抗原が，症状の発現に関与してい ることを示唆する報告もある [37].さらに，ジアルジ アの感染は，腸内細菌叢の覺乱を引き起こし [38]，感 染後の過敏性腸症候群のような慢性消化管障害の原因と なることがある $[39,40]$.

ジアルジアは再感染が一般的である.ジアルジアは細 胞内に侵入しないため, 獲得免疫は強く誘導されず不完 全な状態である [38]。さらに，ジアルジアの表面は， 変異特異的表面蛋白（variant-specific surface proteins : VSPs）で覆われているが，通常，190〜200種 あるVSPs の中から 1 種類だけを発現し，免疫的プレッ シャーがなくても 6〜13 世代ごとにVSPS 遺伝子のスイ ッチングによって表面抗原を変異させ，宿主の免疫から 逃れることで繰り返しの感染を可能にしている $[41$, $42]$.

\section{9 診断}

ジアルジア感染の診断は，粪便検査による虫体の検出 やELISA (enzyme-linked immunosorbent assay)に よる特異抗原の検出，あるいはPCRによるジアルジア 遺伝子の検出によってなされる。最近，日本国内でも 犬・猫用のジアルジア ELISAキットが発売され，簡便 にジアルジアを感度よく検出することが可能になった。 また，検出感度が優れたリアル PCRによる検出も外注 で利用可能である。ただし，ジアルジアの虫体を検出す る粪便検査は，ルーチンに実施すべきである。なぜな ら，ジアルジアのELISA キットやリアルPCRは，ジア ルジアを検出することは可能だが，子犬でジアルジアと 同様に感染率の高いことが示されているイソスポラ $[21,22]$ などの消化管内寄生虫は検出できないからで ある．すなわち，抗原や遺伝子の検出は従来の糞便検査 法に代わるものではなく，併用することでその価值が発 揮されることに留意すべきである，実際の粪便検査で は，直接塗抹法とホルマリン・酢酸エチル沈澱法 [32]， または，浮遊法（硫酸亜鉛液：比重 $1.18 〜 1.20 ）$ を併 用し、ヨード染色を施して観察するのが望ましい。ジア ルジアの検出形態はシストが最も一般的であり，ジアル ジア感染が確認された犬 151 頭における虫体の検出形態 を調べた報告では，シストでの検出がトロフォゾイトと ともに観察された例を含めて約 $90 \%$ を占めた [16]。し かしその一方で，トロフォゾイトだけが観察された例も 1 割程度あった。また，ジアルジアが検出された犬 171 例の粪便性状と原虫検出形態の割合について調査した報 告で，固形便ではシストの検出割合が圧倒的に高いが,
軟便，下痢便となるにつれてトロフォゾイトの検出割合 が高くなり [43]，下痢の激しい例ではシスト形成が間 に合わないために，糞便へトロフォゾイトがそのまま排 泄されるとする報告と一致していた $[32]$ 。これらのこ とは，沈澱法や浮遊法の検出感度が直接塗抹法より高い という理由から，直接塗抹法を省略するとトロフォゾイ 卜を検出することが不可能となり，ジアルジアの寄生を 見逃すことを意味している．以上のことから，直接塗抹 法も必ず実施することが重要である。

診断で注意すべきことは，ライフサイクルで述べたよ うに虫体の排泄は間欠的であり，排泄期間や排泄される 虫体の数に規則性がないことである [34]。すなわち， 虫体が検出されれば感染していることは確かだが，虫体 が検出されないことは必ずしも感染を否定するものでは ない。このことは，虫体の検出より検出感度が優れてい るとされる抗原の検出においても同様である [34]。つ まり，虫体・抗原ともに検出されれば陽性に違いない が，それは過去の成績を否定するものではないし，逆に 陰性であることは将来的にも㓌性であることを保証する ものではない，検査をした時点で陽性，あるいは陰性で あることを示すだけである。より正確な診断には 1 回の みの検査ではなく，間隔をあけて何度かの検査が必要と される.

\section{0 疫学}

犬のジアルジア感染には特異的な臨床症状がないこと から，疫学的背景の聴取，なかでも年齢と由来が診断に 重要なポイントとなる。浮遊法や沈澱法による一般家庭 で飼育されている犬のジアルジア虫体検出率は，海外で $0 \sim 17.0 \%[15,18,44-49]$ ，日本国内では 0 23.4\% $[10,13,14,16,19,20,50]$ と報告されている. 2002〜 2005 年にかけて著者らは, 動物病院に来院した一般家 庭で飼育されている犬 1,020 頭を対象に，人用のELISA キットを用いて G. duodenalis 特異抗原の検出を行った [51]．その結果，16.1\%（164/1,020）が抗原陽性であ り，特に 1 ～ 6 力月齢では陽性率が $22.8 \%(83 / 364)$ と他の年齢群より有意に高かった。ペットショップ／繁 殖施設由来の犬（ペットショップまたは繁殖施設から購 入し，現在は一般家庭で飼育されている犬）では，陽性 率が $20.5 \%$ （130/634）であり，一般家庭由来の $8.8 \%$ （34/386）に比べて有意に高かった。また，粪便性状で は軟便の陽性率が $22.4 \%(50 / 223)$ であり，固形便の 陽性率より有意に高かった。人との接触機会が多いと考 えられる室内飼育の犬 164 頭では，その $83.5 \%$ （137/164）から特異抗原が検出され，人へのジアルジ ア感染に室内飼育犬が保虫宿主として重要な役割を果た す可能性があると考えられた。

2008 ～ 2010 年にかけて犬・猫用の ELISA キットを

日獣会誌 $66 \quad 701 \sim 708 （ 2013 ）$ 
使用し，一般家庭で飼育されている犬 2,365 頭を対象に 著者らが実施した調查では，8.3\% (196/2,365）が抗 原陽性であり，特に，6力月齢以下の陽性率は $31.5 \%$ (142/451) で，7カ月齢以上の $2.3 \%(54 / 1,914)$ に比 較して有意に高かった。また，糞便性状では下痢便の陽 性率が $14.8 \%$ (19/128) で, 固形便の $7.9 \%(177 / 2,237)$ より有意に高かった $[21]$.さらに，最新のデータとし て著者が 2012 年の 1 年間に実施した調查では, 一般家 庭で飼育されている 6 力月齢以下の子犬におけるジアル ジア抗原の陽性率は $30.4 \%$ （41/135）であり, 調查し た犬の $91.1 \%$ （123/135）がペットショップ／繁殖施設 由来であった [未発表]。これらの結果及び以前の調査 成績から，この 10 年間，子犬におけるジアルジアの感 染状沉は，変化していないということができる.

一般家庭の飼育犬における調査で，ジアルジアの感染 源として重要な役割を果たしている可能性が示唆された 日本国内の繁殖施設やペットショップで飼育されている 犬の調査では，繁殖施設内で飼育されている犬 361 頭を 対象とした調査で，全体の抗原陽性率が $37.4 \%$ (135/361）と高く，また，1～9 カ月齢の犬では $54.5 \%$ （54/99）と著しく高いことが示された［17］．日本国内 のペットショップで販売目的に飼育されている子犬の感 染状沉に関しては, 3 力月齢以下の子犬 1,794 頭の調査 で，抗原陽性率が $23.4 \%(420 / 1,794)$ であり, ペット ショップ間で陽性率に差のないことが明らかになった [22]. これらのデータから，子犬の供給源である繁殖施 設やペットショップが子犬のジアルジア感染源であるこ とが裏付けられ，それらの施設での衛生管理が十分でな いことが最大の要因と推察される。そして, 繁殖施設や ペットショップでの感染状況に変化のないことが，一般 家庭飼育の子犬に扔ける感染率が低下しない最大の理由 であると考えられる.ペットショップや繁殖施設と同様 に, 衛生管理の重要性という点では動物病院の入院動物 に関しても注意を払うべきだろう。

疫学調查の成績から明らかなように, 軟便や下痢便で ジアルジア抗原の検出率が高く, ジアルジアの感染が翼 便性状に影響を与えている可能性はある。しかし, 多く のジアルジア感染は，必ずしも下痢を示さない不顕性感 染であり，このことが，繁殖施設やペットショップでの ジアルジア感染を拡大させている原因の一つだろうと思 われる。すなわち，翼便性状に異常がある個体は糞便検 查を受ける機会があるかも知れないが，正常な固形便の 子犬は，検查を受ける機会はかなり少ないだろうと推測 されるからである.

\section{1 分子生物学的疫学}

犬由来ジアルジアの遺伝子型解析は, 犬が人への感染 源となる可能性を評価するために重要なことである。し
かしながら，日本国内における犬由来ジアルジアの遺伝 子型解析は，あまり進んでいないのが現状である．以前 の報告では，犬から分離したジアルジアの 24 検体中， 14 検体が assemblage A，6検体が assemblage D，1 検体が assemblage Cであり，3検体は assemblage A と D の混合であった [8]．人獣共通感染性と考えられる assemblage Aが検出されたことから, 犬から人へのジ アルジア感染の可能性は否定できないが，前述のように 人獣共通感染性を評価するために必要な assemblage A のサブグループ解析がなされていないため，正確な評価 は不可能である．また，国内のペットショップの子犬に おける 29 検体の調查では， assemblage Cが 9 検体， assemblage Dが 20 検体であり，人獣共通感染性の assemblage AやBは検出されなかった [22]．日本国 内の他の報告でも assemblage A は分離されていない [52]。これらの状況や海外での成績から，犬から人への ジアルジア感染は一般的なものではないと推測される が，今後も注意深い監視が必要である.

\section{2 治療に使用される薬剤}

海外では多数の薬剂がジアルジア感染の治療に使用さ れているが，日本国内では販売されていないものが多い. また，犬・人を問わずジアルジア感染の治療薬として承 認されたものはない。いずれの薬郕も1クールの投与で $100 \%$ の効果を期待することは困難であり，副作用の発 現を考虑しながら複数回の投与が必要だと思われる.

現在，犬のジアルジア感染に使用されている薬剤は, 二つの系統に大別される。すなわち，ニトロイミダゾー ル系薬剤とベンズイミダゾール系薬剤である。 ニトロイ ミダゾール系薬戍は，ジアルジアのトロフォゾイトに取 り込まれた後，ニトロ基がピルビン酸フェレドキシンオ キシドレダクターゼ及びフェレドキシン（電子伝達体蛋 白質）の作用により還元されて活性化し，DNAに対し てラセン構造の喪失や塩基置換などの障害を引き起こす ことで抗ジアルジア作用を示す $[53,54]$. また，ジアル ジアのトロフォゾイト細胞質内への酸素とニトロイミダ ゾール系薬剤の取り达みが競合することより，本剤の投 与によりトロフォゾイトの酸素取り込み率が容量依存性 に低下し，トロフォゾイトは非活動性または死に至る $[54,55]$. ベンズイミダゾール系薬剤は，トロフォゾイ 卜の微小管構成蛋白質重合を特異的に阻害して微小管の 構築を妨げ，さらに，グルコースの取り込みを障害する ことでトロフォゾイトの麻痺や死を引き起こし，抗ジア ルジア作用を示す [54, 56].

日本国内で入手可能であり，実際に犬のジアルジア感 染に対して使用され，子犬への投与も可能であると考え られる薬剂と貨便内の虫体検出を指標としたそれぞれの 薬剤の効果に関しては，次のように報告されている. 


\section{ニトロイミダゾール系薬剤}

(1)メトロニダゾール：最も一般的に使用されてい る. $12.5 \sim 32.5 \mathrm{mg} / \mathrm{kg}$ の 1 日 2 回，5～8 日の経 口投与で 1 クール投与の有効率は $50.0 \%$ [57]. (2)チニダゾール：50mg/kgの 1 日 1 回，3日間の経 口投与で 1 クール投与の有効率は $71.4 \%$ [57].

\section{ベンズイミダゾール系薬剤}

ベンズイミダゾール系薬剤を使用した場合には，消 化管内線虫の駆除も同時に可能である。

(1)フェバンテル配合剤：フェバンテルとして $30 \mathrm{mg} / \mathrm{kg}$ を 1 日 1 回 3 日間の経口投与で 1 クール 投与の有効率は $75.0 \%$ [58].

(2)フェンベンダゾール：日本国内では販売されてい ないが，個人輸入で使用可能. $50 \mathrm{mg} / \mathrm{kg}$ の 1 日 1 回，3日間の経口投与で 1 クール投与の有効率は $81.8 \%[58]$.

最近，これらジアルジアの虫体に直接効果がある薬剤 以外に，一部のプロバイオティクスが，ジアルジアの感 染によって生じた腸内細菌叢の乱れを是正することやジ アルジアの排除を促すこと，さらには，in vitroでジア ルジアの発育を抑制することなどが示されている $[30$ ， $40,59]$. 今後, 犬のジアルジア感染に対しての応用も 考慮すべきだろう。

\section{3 おりに}

ジアルジアは，現在に至っても謎多き寄生虫である． 臨床的に治療の面からは，多剂併用やこれまでとはまっ たく異なる薬剤の応用なども考慮しなければならない時 期にきているのかも知れない。また，どのようにすれば シストによる環境污染をコントロールし感染を防御でき るのかなど，衛生管理についても解決すべき課題が山積 している.

\section{引 用 文 献}

[1] Lane S, Lloyd D : Current trends in research into the waterborne parasite Giardia, Crit Rev Microbiol, 28, 123-147 (2002)

[2] Dawson D : Foodborne protozoan parasites, Int J Food Microbiol, 103, 207-227 (2005)

[3 ] Nygard K, Schimmer B, Sobstad O, Walde A, Tveit I, Langeland N, Hausken T, Aavitsland P : A large community outbreak of waterborne giardiasis-delayed detection in a non-endemic urban area, Bio Med Central Public Health, 6, 141 (2006)

[4] Schuster CJ, Ellis AG, Robertson WJ, Charron DF, Aramini JJ, Marshall BJ, Medeiros DT : Infectious disease outbreaks related to drinking water in Canada, 1974-2001, Can J Public Health, 96, 254-258 (2005)

[5] Smith H, Nichols RA : Zoonotic protozoa-food for thought, Parasitologia, 48, 101-104 (2006)
[6 ] Ballweber LR, Xiao L, Bowman DD, Kahn G, Cama VA : Giardiasis in dogs and cats: update on epidemiology and public health significance, Trends Parasitol, 26, 180-189 (2010)

[7] 国立感染症研究所感染症情報センター：感染症発生動向 調查週報，51・52，38（2005）

[8] Itagaki T, Kinoshita S, Aoki M, Itoh N, Saeki H, Sato N, Uetsuki J, Izumiyama S, Yagita K, Endo T : Genotyping of Giardia intestinalis from domestic and wild animals in Japan using glutamate dehydrogenase gene sequencing, Vet Parasitol, 133, 283-287 (2005)

[9] Lalle M, Pozio E, Capelli G, Bruschi F, Crotti D, Caccio SM : Genetic heterogeneity at the $\beta$-giardin locus among human and animal isolates of and identification of potentially zoonotic subgenotypes, Int J Parasitol, 35, 207-213 (2005)

[10] Mochizuki M, Hashimoto M, Ishida T : Recent epidemiological status of canine viral enteric infections and Giardia infection in Japan, J Vet Med Sci, 63, 573-575 (2001)

［11］菅野紘行，深瀬 徹，茅根士郎，板垣 博：あるブリー ダー由来の子犬に扔けるジアルジア症とその発症要因, 日獣会誌，42，68-71（1989）

[12] Watson AD : Giardiasis and colitis in a dog, Aust Vet J, 56, 444-447 (1980)

［13］荒島康友，熊坂一成，河野均也，浅野隆司，保刈成男， 村杉栄治，岩下栄一，西川庄一郎，松尾克徳：Zoonosis としてのジアルジア症に関する研究．III.本邦に扔ける イヌおよび飼育者のジアルジア保有状況，感染症誌，66， 1062-1066 (1992)

[14] Asano K, Suzuki K, Matsumoto T, Sakai T, Asano R : Prevalence of dogs with intestinal parasites in Tochigi, Japan in 1979, 1991 and 2002, Vet Parasitol, 120 243-248 (2004)

[15] Huber F, Bomfim TC, Gomes RC : Comparison between natural infection by Cryptosporidium sp., Giardia sp. in dogs in two living situations in the West Zone of the municipality of Rio de Janeiro, Vet Parasitol, 130, 69-72 (2005)

[16] Itoh N, Muraoka N, Aoki M, Itagaki T : Prevalence of Giardia lamblia infection in household dogs, J Jpn Assoc Infect Dis, 75, 671-677 (2001)

[17] Itoh N, Muraoka N, Saeki H, Aoki M, Itagaki T : Prevalence of Giardia intestinalis infection in dogs of breeding kennels in Japan, J Vet Med Sci, 67, 717718 (2005)

[18] Kirkpatrick CE : Epizootiology of endoparasitic infections in pet dogs and cats presented to a veterinary teaching hospital, Vet Parasitol, 30, 113-124 (1988)

[19］斎藤哲郎，橋口正大，島谷和子，宮野寿美子，山足 清, 山口裕之，吉田邦恵，池田文雄，久家光雄，宇都宮敬三， 頓宮廉正：2002 年福山市内の飼育犬および飼育猫の内 部寄生虫感染状況，獣畜新報，57，11-14（2004）

［20］斎藤哲郎，山口裕之，吉田邦恵，草浦潤子，和田栄津子, 森重和久，頓宮廉正：1995年度の広島県福山市に抢け る飼育犬および飼育猫の寄生虫感染状況，獣畜新報，51， 889-892 (1998)

[21] Itoh N, Kanai K, Tominaga H, Kawamata J, Kaneshi- 
ma T, Chikazawa S, Hori Y, Hoshi F, Higuchi S : Giardia and other intestinal parasites in dogs from veterinary clinics in Japan, Parasitol Res, 109, 253-256 (2011)

[22] Itoh N, Itagaki T, Kawabata T, Konaka T, Muraoka N, Saeki H, Kanai K, Chikazawa S, Hori Y, Hoshi F, Higuchi S : Prevalence of intestinal parasites and genotyping of Giardia intestinalis in pet shop puppies in east Japan, Vet Parasitol, 176, 74-78 (2011)

[23] Adam RD : Biology of Giardia lamblia, Clin Microbiol Rev, 14, 447-475 (2001)

[24] Feng Y, Xiao L : Zoonotic potential and molecular epidemiology of Giardia species and giardiasis, Clin Microbiol Rev, 24, 110-139 (2011)

[25] Monis PT, Caccio SM, Thompson RCA : Variation in Giardia: twards a taxonomic revision of the genus, Trends Parasitol, 25, 93-100 (2009)

[26] Cacció SM, Sporong H : Giardia duodenalis: Genetic recombination and its implications for taxonomy and molecular epidemiology, Exp Parasitol, 124, 107-112 (2010)

[27] Cacció SM, Ryan U : Molecular epidemiology of giardiasis, Mol Biochem Parasitol, 160, 75-80 (2008)

[28] Conn DB, Weaver J, Tamang L, Graczyk TK : Synanthropic flies as vectors of Cryptosporidium and Giardia among livestock and wildlife in a multispecies agricultural complex, Vector Borne Zoonotic Dis, 7, 643-651 (2007)

[29] Doiz O, Clavel A, Morales S, Varea M, Castillo FJ, Rubio C, Gómez-Lus R : House fly (Musca domestica) as a transport vector of Giardia lamblia, Folia Parasitol (Praha), 47, 330-331 (2000)

[30] Roxström-Lindquist K, Palm D, Reiner D, Ringqvis E, Svärd SG : Giardia immunity-an update, Trends Parasitol, 22, 26-31 (2006)

[31] Rosa LAG, Gomes MA, Mundim AV, Mundim MJS, Pozzer EL, Faria ESM, Viana JC, Cury MC : Infection of dogs by experimental inoculation with human isolates of Giardia duodenalis: clinical and laboratory manifestatios, Vet Parasitol, 145, 37-44 (2007)

[32] Kirkpatrick CE : Giardiasis, Vet Clin North Am Small Anim Pract, 17, 1377-1387 (1987)

[33] Tangtrongsup S, Scorza V : Update on the diagnosis and management of Giardia spp infections in dogs and cats, Top Companion Anim Med, 25, 155-162 (2010)

[34］佐伯英治：小動物臨床からみたジアルジアおよびジアル ジア症，動物の原虫病，23，1-9（2008）

[35] Chen N, Upcroft JA, Upcroft P : A Giardia duodenalis gene encoding a protein with multiple repeats of toxin homologue, Parasitology, 111, 423-431 (1995)

[36] Faubert G : Immune response to Giardia duodenalis, Clin Microbiol Rev, 13, 35-54 (2000)

[37] Jiménez JC, Fontaine J, Grzych JM, Dei-Cas E, Capron M : Systemic and mucosal responses to oral administration of excretory and secretory antigens from Giardia intestinalis, Clin Diagn Lab Immunol, $11,152-160$ (2004)

[38] Müller N, Allmen N : Recent insights into the mucos- al reactions associated with Giardia lamblia infections, Int J Parasitol, 35, 1339-1347 (2005)

[39] Cotton JA, Beatty JK, Buret AG : Host parasite interactions and pathophysiology in Giardia inferctions, Int J Parasitol, 41, 925-933 (2011)

[40] Travers MA, Florent I, Kohl L, Greller P : Probiotics for the control of parasites: An overview, J Parasitol Res, 2011, 1-11 (2011)

[41] Prucca CG, Lujan HD : Anitigenic variation in Giardia lamblia, Cell Microbiol, 11, 1706-1715 (2009)

[42] Carranza PG, Lujan HD : New insights regarding the biology of Giardia lamblia, Microbes Infect, 12, 71-80 (2010)

[43］伊藤直之，村岡 登：ジアルジアが検出された犬 171 頭 の粪便の性状と疫学的背景, SA Medicine, 4, 100-104 (2002)

[44] Epe C, Coati N, Schnieder T : Ergebnisse parasitologischer Kotuntersuchungen von Pferden, Wiederkäuern, Schweinen, Hunden, Katzen, Igeln und Kaninchen in den Jahren 1998-2002, Dtsch Tierärztl Wochenschr, 111, 243-247 (2004)

[45] Epe C, Ising-Volmer S, Stoye M : Ergebnisse parasitologischer Kotuntersuchungen von Equiden, Hunden, Katzen und Igeln der Jare 1984-1991, Dtsch Tierärztl Wochenschr, 100, 426-428 (1993)

[46] Jacobs SR, Forrester CPR, Yang J : A survey of the prevalence of Giardia in dogs presented to Canadian veterinary practices, Can Vet J, 42, 45-46 (2001)

[47] Meloni BP, Thompson RCA, Hopkins RM, Reynoldson JA, Gracey M : The prevalence of Giardia and other intestinal parasites in children, dogs and cats from aboriginal communities in the Kimberley, Med J Aust, 158, 157-159 (1993)

[48] Ramirez-Barrios RA, Barboza-Mena G, Munoz J, Angulo-Cubillan F, Hernandez E, Gonzalez F, Escalona F : Prevalence of intestinal parasites in dogs under veterinary care in Maracaibo, Venezuela, Vet Parasitol, 121, 11-20 (2004)

[49] Taranto NJ, Passamonte L, Marinconz R, Marzi MC, Cajal SP, Malchiodi EL : Zoonotic parasitosis transmitted by dogs in the Chaco Salteno, Argentina, Medicina (B Aires), 60, 217-220 (2000)

[50］斎藤哲郎，森重和久，頓宮廉正：広島県福山市に抢ける 飼育犬および飼育猫の寄生虫感染状況，寄生虫誌，44， 149-153 (1995)

[51] 伊藤直之, 板垣 匡：飼育イヌのGiardia intestinalis 感染状況と分離株の遺伝子型，獣医寄生虫誌，5，17-25 (2007)

[52] Yoshiuchi R, Matsubayashi M, Kimata I, Furuya M, Tani H, Sasai K : Survey and molecular characterization of cryptosporidium and Giarda spp. in owned companion animal, dogs and cats, in Japan, Vet Parasitol, 174, 313-316 (2010)

[53] Fung HB, Doan TL : Tinidazole: a nitroimidazoles antiprotozoal agent, Clin Ther, 27, 1859-1884 (2005)

[54] Minenoa T, Avery MA : Giardiasis: recent progress in chemotherapy and drug development, Curr Pharm Des, 9, 841-855 (2003) 
[55] Jarroll EL, Sener K : Potential drug targets in cystwall biosynthesis by intestinal protozoa, Drug Regist Updat, 6, 239-246 (2003)

[56] Lacy E : Mode of action of benzimidazoles, Parasitol Today, 6, 112-115 (1990)

［57］伊藤直之，村岡 登：犬のジアルジア症，獣畜新報，54,
713-716 (2001)

［58］伊藤直之，村岡 登，青木美樹子，板垣 匡，伊藤 さや子：ベンズイミダゾール系薬片による犬ジアルジア 症の治療，日獣会誌，55，739-743（2002）

[59] Eckmann L : Mucosal defenses against Giardia, Parasite Immunol, 25, 259-270 (2003) 